\title{
CHEMICAL ANALYSIS AND THE STUDY OF QUALITY INDICATORS OF THE IMMUNOBIOLOGICAL DRUG FOR PREVENTING AND TREATING CANDIDAL INFECTIONS
}

\author{
Mykola Rybalkin ${ }^{1} \otimes$, Leonid Strelnikov ${ }^{1}$, Oksana Strilets $^{1}$, Olha Kaliuzhnaia ${ }^{1}$, \\ Sergiy Kutsenko ${ }^{2}$
}

https://doi.org/10.23939/chcht14.04.455

\begin{abstract}
Quality indicators such as protein content, polysaccharide content, phenol content, and $\mathrm{pH}$ of the developed vaccine solution for injection (VSI) "Candidocyde" based on cells of $C$. albicans and $C$. tropicalis fungi have been found to meet the standard requirements. It was determined that by the indicator of transparency and degree of turbidity the test solution is transparent, by the coloration degree it is colorless, by the sterility indicator it is sterile. The sterility period, determined after the first opening, is 8 hours. It was found that no solid particles were present in the solution; the container with the solution is hermetic; the volume of the container with a solution is not less than $5.0 \mathrm{ml}$. The test solution is stable for 2 years of storage at $275-265 \mathrm{~K}$.
\end{abstract}

Keywords: vaccine, antigen, chemical composition, proteins, polysaccharides.

\section{Introduction}

In recent years, there has been an increase in the incidence of fungal infections worldwide, among them candidiasis occupies a leading place. Candidiasis is an infectious disease caused by yeast-like fungi of the genus Candida. There are both light forms of this disease candidiasis of the skin and mucous membranes and very severe forms - generalized candidiasis of internal organs [1]. Half a century ago only $5 \%$ of people on the planet had candidiasis. Currently, according to the World Health Organization data every fifth person on the planet, i.e. $20 \%$ of people, has candidiasis [2]. The definite forms of candidiasis (acute disseminated or generalized candidiasis, and candidemia) are characterized by high mortality (30-

\footnotetext{
${ }^{1}$ Department of Biotechnology, National University of Pharmacy, Kharkiv, Ukraine

${ }^{2}$ Department of Industrial Technology of Drugs, National University of Pharmacy, Kharkiv, Ukraine

«ibalkin.nikolay@gmail.com

(C) Rybalkin M., Strelnikov L., Strilets O., Kaliuzhnaia O., Kutsenko S., 2020
}

$70 \%)[3,4]$. According to the epidemic characteristics the tendencies of increasing candidiasis incidence are approximately similar in the Eastern and Western hemisphere. In the United States according to the National system of surveillance of nosocomial infections candidiasis is in the list of nosomycosis infections, and it takes the fourth place in prevalence [5, 7]. Such a state of candidiasis incidence exists also in European countries according to the program "European prevalence of infection under conditions of intensive treatment" $[6,7]$. A similar situation with the incidence of candidiasis has developed in the CIS countries. This is due to the fact that the similar risk factors causing candidiasis "act" in the world. In recent years, there has been a shift in the pathogens of candidiasis from species of C. albicans to other non-albican species, such as $C$. tropicalis, $C$. parapsilosis, C. glabrata and C. krusei.

Drugs for the treatment of candidiasis are practically limited to antifungal antibiotics and imidazole derivatives. They suppress the immune system and adversely affect the human body. Their long-term use leads to the appearance of resistant strains of the pathogen. C. albicans fungi have a high sensitivity to anti-fungal drugs although they are able to develop rapid resistance to them.

C. albicans has a high sensitivity to anti-fungal drugs although it is able to quickly develop resistance to them. Through the increased use of fluconazole in recent years Candida genus fungi are often not sensitive to it. The second problem worldwide is the increasing prevalence of various species of fungi of this genus (nonalbicans). Some fungi from the very beginning are not sensitive to azoles, while it is common practice to start treatment with them [12-14]. In 2016, an outbreak of Candida auris, with a mortality rate of $60 \%$, which was not susceptible to all antifungal drugs, was recorded [15]. In this regard, for the treatment of candidiasis diseases, and the promising use of specific stimulation of protective mechanisms of the body it is urgent to develop a vaccine based on fungi of the genus Candida for the prevention and treatment of candidal infection. 
To control candidal infection in recent years, vaccines with immune modulating properties are actively studied in the CIS countries, as well as in countries of Europe and America. Nova Digm Therapeutics, a pharmaceutical company, is developing innovative vaccines to protect patients from fungal and bacterial diseases that can be recurrent, drug-resistant and, in some cases, life-threatening. Based on the market research Nova Digm Therapeutics predicts the annual sales of a candidal vaccine in the USA in the amount up to 1 billion US dollars. Nova Digm Therapeutics plans to produce a vaccine for the treatment of candidiasis in 2020. The pharmaceutical company Pevion Biotech AG develops biopharmaceutical vaccines, conducts preclinical and clinical studies of preventive and therapeutic vaccines. The company develops vaccines for breast cancer, influenza, and candidiasis. Pevion Biotech AG plans to produce a vaccine to treat candidiasis in 2020 [16-19].

It should be noted that currently no domestic vaccine is produced in Ukraine and no imported vaccines for the prevention and treatment of candidiasis (PTC) have been registered. Therefore, development of a vaccine against candidal infection is the topical issue of modern medicine and pharmacy.

To control candidiasis the authors previously developed the vaccine solution for injection (VSI) for the prevention and treatment of candidal infection. In accordance with the studies conducted the following composition of the VSI based on the associated antigens of C. albicans and C.tropicalis fungi under the conventional name "Candidocyde" per $1 \mathrm{ml}$ has been proposed: proteins and polysaccharides of $C$. albicans and $C$. tropicalis fungi with the protein concentration of $4 \mathrm{mg} / \mathrm{ml}(0.004 \mathrm{~g})$, the polysaccharide concentration in the extract of $17 \mathrm{mg} / \mathrm{ml}(0.017 \mathrm{~g})$, the phenol concentration of $0.25 \%(0.025 \mathrm{~g})$, and phosphate buffer of $1 \mathrm{ml}$ [20]. Antigens of fungi (proteins and polysaccharides) $C$. albicans and $C$. tropicalis were obtained by ultrasound, which is widely used for the clearance and disinfection of microorganisms [21, 22]. The drug developed has a protective and therapeutic effect.

According to the State Pharmacopoeia of Ukraine [23], vaccines are controlled by the following indicators: description, qualitative and quantitative determination of substances in the composition of the vaccine solution, transparency, degree of coloration, sterility, container integrity, $\mathrm{pH}$, container volume, the shelf life after the first opening, control of particulate matter and the VSI activity. Depending on nature, additional tests can be performed to control the quality and specific toxicity of the vaccine; they are given in a separate monograph. If it is reasonable, it is allowed to determine the shelf life of the final batch of the drug from the date of completion of the quantitative determination.
In order to assess the quality of the VSI under the conventional name "Candidocyde" and further development of the quality control methods (QCM) its physical and chemical parameters have been studied; the research on development of the method for the quantitative and qualitative analysis of active substances has been conducted. So, the aim of this work was to study the quality indicators of the VSI developed under the conventional name "Candidocyde" for PTC.

\section{Experimental}

All determinations were performed according to the requirements of the State Pharmacopoeia of Ukraine [23].

Qualitative determination of proteins was performed simultaneously with quantitative determination. The content of the container with "Candidocyde" VSI was transferred into a $200 \mathrm{ml}$ volumetric flask and diluted with water to the level. $1 \mathrm{ml}$ of the resulting solution was placed in a glass test tube, then $0.15 \mathrm{ml}$ of trichloracetic acid solution (400 g/l) was added, shaken, kept for $15 \mathrm{~min}$, and centrifuged for $10 \mathrm{~min}$ at a speed of $5000 \mathrm{rpm}$. The supernatant was removed. $0.4 \mathrm{ml}$ of $0.1 \mathrm{M}$ sodium hydroxide solution was added to the precipitate.

$2 \mathrm{ml}$ of copper-tartrate solution was added to the test tube, shaken and kept for $10 \mathrm{~min} .0 .2 \mathrm{ml}$ of the phosphorus-tungsten mixture (1:1) prepared immediately before use was also added to the test tube. The test tube was closed with a stopper, shaken, and kept in a dark place for $30 \mathrm{~min}$.

Quantitative determination of proteins. The content of the container with "Candidocyde" VSI was transferred into a $10 \mathrm{ml}$ volumetric flask and diluted with water to the level. $1 \mathrm{ml}$ of the resulting solution was placed in a glass test tube, then $0.15 \mathrm{ml}$ of trichloracetic acid solution $(400 \mathrm{~g} / \mathrm{l})$ was added, shaken, kept for $15 \mathrm{~min}$, and centrifuged for $10 \mathrm{~min}$ at a speed of $5000 \mathrm{rpm}$. The supernatant was removed. $0.4 \mathrm{ml}$ of $0.1 \mathrm{M}$ sodium hydroxide solution was added to the precipitate.

The standard solution was prepared as follows: $0.100 \mathrm{~g}$ of bovine albumin was dissolved in $100 \mathrm{ml}$ of $0.1 \mathrm{M}$ sodium hydroxide solution (the main solution containing $1 \mathrm{~g} / \mathrm{l}$ of protein). $1 \mathrm{ml}$ of the main solution was diluted to $20 \mathrm{ml}$ with $0.1 \mathrm{M}$ sodium hydroxide solution (the working solution $1 ; 50 \mathrm{mg} / 1$ of protein). $1 \mathrm{ml}$ of the main solution was diluted to $4 \mathrm{ml}$ with $0.1 \mathrm{M}$ sodium hydroxide solution (the working solution $2 ; 250 \mathrm{mg} / \mathrm{l}$ of protein). The working solutions 1 and 2 were placed in six glass tubes (volume of $0.10,0.20,0.40$ for the solution 1 and $0.15,0.20,0.25 \mathrm{ml}$ for the solution 2). The solution in each test tube was diluted to the volume of $0.40 \mathrm{ml}$ with $0.1 \mathrm{M}$ sodium hydroxide solution. 
The blank solution was prepared using $0.40 \mathrm{ml}$ of $0.1 \mathrm{M}$ sodium hydroxide.

$2 \mathrm{ml}$ of copper-tartrate solution was added to each test tube, then the tube was shaken and kept for $10 \mathrm{~min}$. $0.2 \mathrm{ml}$ of the phosphorus-tungsten reagent mixture $(1: 1)$ prepared immediately before use was added to each tube. The test tubes were closed with a stopper; the content was mixed by shaking, and kept in a dark place for $30 \mathrm{~min}$. The solutions were colored in blue; this color was stable for $60 \mathrm{~min}$. If necessary, they were centrifuged to obtain clear solutions.

The optical density of each solution was measured at a wavelength of $760 \mathrm{~nm}$ [23] using the blank solution as the comparative one. The calibration curve of the optical density dependence on the protein content was constructed, and the protein content in the test solution was determined by the calibration curve.

Qualitative determination of polysaccharides. The presence of free sugars was studied using the reaction with the copper-tartrate reagent. The test tube was loaded with $2 \mathrm{ml}$ of VSI and 5 drops of concentrated hydrochloric acid and heated for $15 \mathrm{~min}$. The acidic medium was neutralized with $10 \%$ potassium hydroxide solution to $\mathrm{pH} 7$ determined by the universal indicator. Then $2 \mathrm{ml}$ of the copper-tartrate reagent was added to the test tube. The tube was boiled for $1 \mathrm{~min}$ and left in a testtube support for $10 \min$ [14].

Quantitative determination of polysaccharides was performed by the gravimetry according to the method given in [23]. $5 \mathrm{ml}$ of the VSI was placed in a $250 \mathrm{ml}$ flask with a ground glass stopper and $100 \mathrm{ml}$ of water was added. The mixture was boiled with a reflux condenser for $30 \mathrm{~min}$, cooled, centrifuged at a speed of $5000 \mathrm{rpm}$ for $10 \mathrm{~min}$ and decanted into a $250 \mathrm{ml}$ volumetric flask through a glass watering can with 5 layers of gauze premoistened with water $(R)$. Extraction was performed in 2 portions: the first one $-100 \mathrm{ml}$ of water, and the second portion $-50 \mathrm{ml}$ of water; each time it was boiled with a reflux for $30 \mathrm{~min}$. Each extract was cooled, centrifuged at a speed of $5000 \mathrm{rpm}$ for $10 \mathrm{~min}$ and decanted into the same volumetric flask. The filter was washed with water, and the solution was diluted to the volume with water.

$25 \mathrm{ml}$ of the resulting solution was placed in a centrifuge tube and $75 \mathrm{ml}$ of $96 \%$ alcohol was added. The tube was stirred, heated on a water bath at $303 \mathrm{~K}$ for $5 \mathrm{~min}$, kept for $1 \mathrm{~h}$ and centrifuged at a speed of $5000 \mathrm{rpm}$ for $30 \mathrm{~min}$. The supernatant was filtered under vacuum at a residual pressure of $13-16 \mathrm{kPa}$ through a POR 16 glass filter pre-dried at $373-378 \mathrm{~K}$ to a constant mass. The precipitate was quantitatively transferred to the filter with $15 \mathrm{ml}$ of the mixture $R$ and $96 \%$ alcohol; then it was successively washed with $15 \mathrm{ml}$ of $96 \%$ alcohol, $10 \mathrm{ml}$ of acetone, and $10 \mathrm{ml}$ of ethyl acetate. The filter with the precipitate was first dried in air, then - at $373-378 \mathrm{~K}$ to a constant weight. The content of polysaccharides equivalent to a dry raw material was calculated by the formula:

$$
X=\frac{\left(m_{2}-m_{1}\right) \cdot 100000}{m(100-W)}
$$

where $m$ is the weight of the raw material tested, g; $m_{1}$ is the filter weight, $\mathrm{g} ; m_{2}$ is the filter weight with the residue, $\mathrm{g} ; W$ is the weight loss on drying, $\%$.

Each sample was examined five times to determine the relative standard deviation. The content of polysaccharides in $1 \mathrm{ml}$ should be in the range from 16.8 to $17.2 \mathrm{mg}$.

Determination of the phenol content. $1 \mathrm{ml}$ of the VSI solution 1 was placed in a $100 \mathrm{ml}$ volumetric flask and diluted to the volume with water so that the resulting solution contained about $25 \mu \mathrm{g} / \mathrm{ml}$ of phenol. The standard phenol solutions containing 5,10,15, 20 and $30 \mu \mathrm{g} / \mathrm{ml}$ of phenol, respectively, were prepared. $5.0 \mathrm{ml}$ of aminopyrazole solution and $5.0 \mathrm{ml}$ of potassium ferricyanide solution were added to $5.0 \mathrm{ml}$ of the test solution and each standard buffer solution ( $\mathrm{pH} 9.0)$. After keeping for $10 \mathrm{~min}$, the optical density was measured at a wavelength of $546 \mathrm{~nm}$. The calibration curve was plotted, and the phenol content in the test sample was calculated.

Determination of transparency and turbidity. The identical flat bottom test tubes of colorless transparent neutral glass with an internal diameter of $20 \mathrm{~mm}$ were used for the determination. The $40 \mathrm{~mm}$ layer of "Candidocyde" vaccine solution was compared with that of the solvent phosphate buffer solution. The liquids were compared in the scattered daylight, observing the samples along the vertical axis of the test tubes on a black background.

Determination of the coloration degree. The identical test tubes of colorless, transparent, neutral glass with an outer diameter of $12 \mathrm{~mm}$ were used for the determination. $2.0 \mathrm{ml}$ of "Candidocyde" was compared with that of phosphate buffer $1 \mathrm{M}$ solution with $\mathrm{pH} 7.2 \pm 0.2$. The coloration was compared in the scattered daylight, observing the samples horizontally (perpendicular to the axis of the test tubes) on a white background.

Determination of $\boldsymbol{p H}$. The results of the study of the effect of physical and chemical factors on the activity of "Candidocyde" VSI (see below) showed that the vaccine was stable at $\mathrm{pH} 7.2 \pm 0.2$ corresponding to the requirements. The $\mathrm{pH}$ value was determined potentiometrically [23] for 26 months with the measurement interval of 3 months.

In order to determine the shelf life and storage conditions, the hydrogen index of the drug developed was monitored with a $\mathrm{pH}$ meter. Two batches of the tested samples were stored at refrigerator $(275-281 \mathrm{~K})$ and room temperature (288-298 K).

The volume of the container content. Since the container volume with "Candidocyde" VSI is more than 
$3 \mathrm{ml}$ and less than $10 \mathrm{ml}$, three containers were taken for the studies. The entire content of each container was separately collected with a dry syringe, which capacity did not exceed the triple measured volume, with a needle of 21 calibers with a length of not less than $2.5 \mathrm{~cm}$. Air bubbles were removed from the syringe and needle, without emptying the needle the content of the syringe was transferred into a dry standardized cylinder (graduated, with a capacity of more than the expected extracted volume) of such a size that the measured volume filled at least $40 \%$ of the nominal volume of the cylinder.

The volume of the container content extracted from the VSI was not less than the nominal volume specified on the label $-5.0 \mathrm{ml}$.

Since the container with "Candidocyde" is multidose, it was necessary to check the extraction of all specified doses from it according to the requirements [23]. For this purpose, one container with the vaccine was selected, and the test was carried out as described for single-dose containers using as many separate sets of syringes as many doses were indicated.

Container integrity. Vials with "Candidocyde" were tested for integrity in a vacuum closed container, where the vials were placed in cassettes with the lid down; the container was filled with water at room temperature, and methylene blue was added to the coloring liquid solution with a concentration of $0.01 \%$. The principle of operation was based on the difference in pressure in the working tank and vials; a vacuum of $0.05-0.07 \mathrm{MPa}$ was formed. When the vacuum was turned off, the coloring liquid entered the leaky bottles. The vacuuming process was repeated 2-3 times.

Control of particulate matter. The pasted labels from the container with "Candidocyde" were removed; the container was washed and dried. Then it was gently rotated or turned round, avoiding formation of air bubbles, and viewed for about $5 \mathrm{~s}$ in front of the white screen. This procedure was repeated in front of the black screen.

Determination of the sterility period after the first opening of the primary packaging. "Candidocyde" is a sterile product, therefore, it is necessary to determine the shelf life after the first opening of the primary packaging. The shelf life was determined by opening the package and then determining the VSI sterility. Sterility was determined every hour after the first opening of the primary packaging.

Determination of sterility. The tested sample was introduced into the culture medium, inoculated with microorganisms (S. aureus, Ps. aeruginosa, E.coli, C. albicans, A. Niger) in the amount of 10-100 CFU.

The sterility test was performed by a membrane filtration. The membrane filter was washed with sterile solution and inoculated on the appropriate culture medium. The container content $(5 \mathrm{ml})$ was diluted to
$100 \mathrm{ml}$ with sterile $0.9 \%$ sodium chloride solution and immediately filtered through a filter with a pore diameter of $0.22 \mu \mathrm{m}$. After filtration the filter was washed at least three times, cut, and one part of it was placed in the thioglycol medium, incubated for 14 days at the temperature of $306 \pm 2 \mathrm{~K}$ (to detect bacteria). The second part was introduced into the casein digest soy lecithin medium and incubated for 14 days at the temperature of $296 \pm 2 \mathrm{~K}$ (to detect fungi).

The cultures were examined periodically during and after the incubation period; the presence of the microbial growth was visually noted. The VSI satisfied the sterility test if no growth of microorganisms was detected by visual inspection. If the microbial growth was present, the drug was considered to have failed the sterility test.

Test for safety. Healthy two-month white mice weighing 17-22 $\mathrm{g}$ (by 6 animals in control and experimental groups) were kept under the same conditions on a standard diet. Before the study, the animals were acclimatized under the experimental room conditions. The VSI developed was intramuscularly injected to mice into the upper part of the posterior right paw in the volume of $0.2 \mathrm{ml}$, after that the local and general reactions of the body were assessed for 10 days.

Immunogenicity studies when preventing candidiasis. To assess the activity of the VSI it was intramuscularly injected to mice into the upper part of the posterior right paw in the amount of $0.2 \mathrm{ml}$. In 14 days the VSI developed in the amount of $0.2 \mathrm{ml}$ was re-injected into the upper part of the posterior left paw. In 1 and 3 months after immunization, the experimental animals were infected abdominally. For this purpose, the suspensions of C.albicans fungi in the amount of 20 million cells and C. tropicalis fungi in the amount of 60 million cells in the volume of $1 \mathrm{ml}$ were injected with an interval of $1 \mathrm{~h}$. In 14 days the titers of antibodies (for C. albicans) were determined when conducting the immunoassay and evaluation of the effectiveness.

Studies of immunogenicity when treating candidiasis. Mice were infected intraperitoneally with the suspension of C.albicans fungi in the amount of 20 million cells and C. tropicalis fungi in the amount of 60 million cells in the volume of $1 \mathrm{ml}$ with an interval of $1 \mathrm{~h}$. In 5 days the VSI was intramuscularly injected to mice into the upper part of the posterior right paw in the amount of $0.2 \mathrm{ml}$. In 14 days the VSI developed in the amount of $0.2 \mathrm{ml}$ was re-injected into the upper part of the posterior left paw. In 14 days the protective functions of the animal body were determined by the titer of specific antibodies (for C.albicans) when conducting the immunoassay and evaluation of the effectiveness.

Determination of abnormal toxicity. Abnormal toxicity of the VSI for PTC was studied on mice and 
guinea pigs. Before the study, the animals were acclimatized under the experimental room conditions.

Five white mice weighing 17-22 $\mathrm{g}$ and two guinea pigs weighing $200-300 \mathrm{~g}$ grown on a standard diet were abdominally injected with $0.2 \mathrm{ml}$ of the VSI. Animals of the control group were administered by the phosphatebuffer solution with $\mathrm{pH}$ of 7.2 \pm 0.2 . Observation of animals was performed within 7 days.

To assess the toxic effect of the VSI on the animals the body weight dynamics was studied. The results were compared with the dynamics of the body weight of the intact group.

\section{Results and Discussion}

The main indicators of the qualitative content of substances in "Candidocyde" VSI were the determination of proteins, polysaccharides, and phenol. Determination of the content of active substances is of great importance since the amount of active substances less than the norm will not provide the necessary therapeutic effect, while the excessive content can lead to overdose, allergic and other side effects, and it is economically unprofitable to introduce an excessive amount of active substances. According to the requirements [23], first of all, it is necessary to determine the content of proteins, which are the main active substances that provide activation of immune reactions in the body. It is also necessary to take into account that the excessive protein content can lead to allergization of the body. According to the data obtained in the qualitative determination of proteins the solution had a blue color, which was stable for $60 \mathrm{~min}$, indicating the presence of protein in the VSI developed. The protein content in $1 \mathrm{ml}$ was found to be in the range of 3.8$4.2 \mathrm{mg}$, meeting the requirements of the standard.

In addition to proteins, polysaccharides also have antigenic properties. The excessive content of polysaccharides can lead to allergization of the body, and the amount of polysaccharides less than normal will not provide a therapeutic effect. When determining polysaccharides content, a brick-red precipitate of copper oxide was observed. This means the presence of free sugars in the test samples of the VSI. The content of polysaccharides in $1 \mathrm{ml}$ was found to be within the range of $16.8-17.2 \mathrm{mg}$, meeting the requirements of the standard.

Phenol provides long-term storage of the VSI, however, in high concentrations it can harm the body. According to the results obtained, the phenol content in $1 \mathrm{ml}$ was in the range of $16.8-17.2 \mathrm{mg}$. This value is within the standard range.

The VSI developed was tested on transparency, coloration and turbidity as required by the standard [23] since the lack of transparency, appearance of coloration or turbidity indicates certain chemical reactions that may lead to inactivation of active substances or appearance of other dangerous compounds adversely affecting the body. "Candidocyde" VSI was considered transparent and colorless since it was visually compared to the solvent used for the VSI preparation under conditions described above.

The degree of coloration showed that the solution was colorless since it was visually compared to the solvent used for the VSI preparation under conditions described above.

The $\mathrm{pH}$ value is of great importance since the acidic or alkaline medium indicate a loss of therapeutic properties of the VSI and lead to negative consequences when introduced to the body. The determined $\mathrm{pH}$ of "Candidocyde" is $7.2 \pm 0.2$ and meets the requirements of the standard.

The next step was to determine the volume of the VSI container. Nonconformity in the volume of the container can lead to the absence of the required number of therapeutic doses, and the excess volume is irrational from the economic point of view. It was found that the volumes extracted were those that provided the extraction of nominal dose specified with each syringe $-0.2 \mathrm{ml}$. As a result of the studies in determining the volume of the container content of the VSI under the conventional name "Candidocyde", it was found that it corresponded to the norm.

The VSI developed was tested on integrity since the absence of integrity could lead to the VSI leakage from the container or chemical oxidation reactions might occur in contact with oxygen affecting the therapeutic activity of the active substances. The containers with "Candidocyde" were hermetic; the VSI did not turn blue.

All solutions for injection should be checked for the absence of particulate matter [23]. The presence of particulate matter indicates imperfection of the manufacturing process of the drug and the danger to consumers. It was found that "Candidocyde" was free of particles.

Solutions for injection in multi-dose containers must be checked for the sterility term after the first opening in accordance with the requirements [23]. The "Candidocyde" VSI may be injected to patients within a few hours. If after opening the primary packaging the VSI immediately loses sterility, other therapeutic doses from the multi-dose container cannot be used because it is dangerous for patients, and therefore, is economically unprofitable. According to the experimental results the sterile period of "Candidocyde" was $8 \mathrm{~h}$.

It was necessary to determine the shelf life of the VSI. The shelf life which is less than the specified period indicates imperfection of the process and can lead to economic losses. Based on the stability studies it was found that the shelf life of "Candidocyde" was 2 years. 
Regarding the safety of the VSI developed, it was found that the intramuscular injection of the VSI did not cause any local reactions. General reactions were within normal limits, all animals remained alive throughout the experiment. Therefore, it can be argued that "Candidocyde" is harmless.

The study of immunogenicity in the prevention of candidiasis is one of the main tests for the developed VSI since they show the activation of protective immune reactions in the body. The results of the study (Table 1) showed that the introduction of "Candidocyde" VSI in 1 and 3 months provided an increase in the level of specific antibodies (for C. albicans) by 8 times, and in 12 months by 4 times compared to the titer of antibodies in animals before the study.

It was also found that the "Candidocyde" VSI protected $90 \%$ of animals from infection in 1 and 3 months. The animals of the control group showed signs of infection, which corresponded to the moderate and developed forms of the disease (Table 2).

The study of immunogenicity in the treatment of candidiasis is also one of the main tests for the VSI developed since they show the activation of protective immune reactions in the body. The results of the study (Table 3) showed that the introduction of the "Candidocyde" VSI provided an increase in the level of specific antibodies (for C. albicans) by 8 times compared to the titer of antibodies in animals before the study.

The therapeutic effect began to manifest itself in 10-14 days after the first injection of the VSI, and there was a complete recovery of animals in 10-14 days after repeated injection of the VSI. The therapeutic effect of the VSI under the conventional name "Candidocyde" was $90 \%$. The results of the study are given in Table 4 .

The antibody titers when preventing candidiasis

\begin{tabular}{|c|c|c|c|}
\hline Time & Healthy animals & In 1 month & In 3 months \\
\hline Antibody titers & $1:(450 \pm 18)$ & $1:(3600 \pm 147)$ & $1:(3600 \pm 153)$ \\
\hline
\end{tabular}

Note: $n=10, \mathrm{P}<0.05$

Table 2

The effectiveness of the VSI when preventing candidiasis

\begin{tabular}{|c|l|c|c|c|}
\hline \multicolumn{2}{|c|}{ Animals } & Prior to injection & In 1 month & In 3 months \\
\hline \multirow{2}{*}{$\begin{array}{c}\text { Quantity of } \\
\text { animals, } \\
\%\end{array}$} & healthy & 90 & 90 & 90 \\
\cline { 2 - 5 } & diseased & 10 & 10 & 10 \\
\cline { 2 - 5 } & dead & 0 & 0 & 0 \\
\hline
\end{tabular}

Note: $n=10, \mathrm{P}<0.05$

Table 3

Titers of antibodies when treating candidiasis

\begin{tabular}{|c|c|c|c|}
\hline Animals & Healthy animals & Diseased animals & Immunized animals \\
\hline Antibody titers & $1:(350 \pm 14)$ & $1:(700 \pm 29)$ & $1:(2800 \pm 118)$ \\
\hline
\end{tabular}

Note: $n=10, \mathrm{P}<0.05$

The therapeutic effect of the VSI in candidiasis

\begin{tabular}{|c|l|c|c|}
\hline Animals & \multicolumn{1}{|c|}{ Healthy animals } & Diseased animals & Immunized animals \\
\hline \multirow{3}{*}{ Number of animals, \% } & healthy & 0 & 90 \\
\cline { 2 - 4 } & diseased & 0 & 10 \\
\cline { 2 - 4 } & dead & 100 & 0 \\
\hline
\end{tabular}

Note: $n=10, \mathrm{P}<0.05$ 
The next step was the study of abnormal toxicity. Animals remained neat, active, had a satisfactory appetite, reacted to sound and light stimuli, urination and defecation processes were normal, respiratory disorders and seizures were not observed. The reflex excitability of animals was normal. The animal skin was also normal. All animals remained active until the end of the experiment. There was no animal death. The results of the test on abnormal toxicity are shown in Table 5.

The study of the body mass in dynamics (Table 6) showed that in groups of animals after intraperitoneal injection of the VSI during the observation period there was a slight fluctuation in the body mass in the positive direction. However, these indicators did not have statistically significant differences from the group of indicators of the intact control animals.
After the end of the observation period, the autopsy and macroscopic examination of the internal organs of animals were performed; signs of intoxication or other manifestations of pathological processes were revealed. The mass coefficients of the internal organs of animals for identification of pathology were determined. There were no signs of intoxication or other manifestations of pathological processes. In size, color, consistency, and location the internal organs of animals did not go beyond the norm and did not differ from the internal organs of the group of intact animals. As evidenced by the data of the mass coefficients of the internal organs of animals, there was no visible pathology in the mass coefficients of the internal organs of animals (Table 7).

Table 5

The study of abnormal toxicity

\begin{tabular}{|c|c|c|}
\hline \multirow{2}{*}{ The drug volume, $\mathrm{ml}$} & \multicolumn{2}{|c|}{ Dead / alive, number of animals } \\
\cline { 2 - 3 } & Mice & Guinea pigs \\
\hline 0.2 & $0 / 5$ & $0 / 2$ \\
\hline
\end{tabular}

Table 6

Dynamics of the animals body weight

\begin{tabular}{|l|l|c|c|c|}
\hline \multirow{2}{*}{ The species and gender of the animal } & \multirow{2}{*}{ Group of animals } & \multicolumn{3}{|c|}{ The body mass dynamics, $\mathrm{g}$} \\
\cline { 3 - 5 } & & initial data & 3 days & 14 days \\
\hline \multirow{2}{*}{ Mice (females) } & Experimental & $22.41 \pm 0.52$ & $22.78 \pm 0.48$ & $24.53 \pm 1.14$ \\
\cline { 2 - 5 } & Intact control & $21.38 \pm 0.51$ & $22.42 \pm 0.67$ & $23.98 \pm 0.85$ \\
\hline \multirow{2}{*}{ Guinea pigs (females) } & Experimental & $238.63 \pm 7.73$ & $239.27 \pm 8.12$ & $241.35 \pm 9.23$ \\
\cline { 2 - 5 } & Intact control & $237.43 \pm 7.54$ & $240.32 \pm 8.47$ & $242.28 \pm 9.71$ \\
\hline
\end{tabular}

Notes: mice $n=5$; guinea pigs $n=2, \mathrm{P}<0.05$

Table 7

Mass coefficients of internal organs of animals when studying abnormal toxicity of the VSI

\begin{tabular}{|c|c|c|c|}
\hline & \multirow{3}{*}{ Indicator } & \multicolumn{2}{|c|}{ The mass coefficient of the organ, $\%$} \\
\hline & & vaccine & control \\
\hline & & \multicolumn{2}{|c|}{ Mice } \\
\hline \multicolumn{2}{|l|}{ Liver } & $4.80 \pm 0.17$ & $4.47 \pm 0.15$ \\
\hline \multirow{2}{*}{ Kidneys } & right & $0.52 \pm 0.02$ & $0.51 \pm 0.02$ \\
\hline & left & $0.52 \pm 0.02$ & $0.51 \pm 0.02$ \\
\hline \multicolumn{2}{|l|}{ Lungs } & $0.86 \pm 0.03$ & $0.87 \pm 0.03$ \\
\hline \multicolumn{2}{|l|}{ Adrenals } & $0.07 \pm 0.01$ & $0.05 \pm 0.01$ \\
\hline \multicolumn{2}{|l|}{ Heart } & $0.46 \pm 0.01$ & $0.48 \pm 0.01$ \\
\hline \multicolumn{2}{|l|}{ Spleen } & $0.67 \pm 0.03$ & $0.87 \pm 0.03$ \\
\hline \multicolumn{2}{|l|}{ Thymus } & $0.31 \pm 0.01$ & $0.28 \pm 0.01$ \\
\hline
\end{tabular}

Note: $n=10, \mathrm{P}<0.05$

\section{Conclusions}

It has been found that all quality indicators of the VSI developed under the conventional name "Candidocyde" based on cells of C.albicans and C. tropicalis fungi meet the following requirements: the protein content, polysaccharide content, phenol content, appearance, sterility, $\mathrm{pH}$, container integrity, container volume; it is stable for 2 years of storage in a glass vial in a dark place at the temperature of $275-265 \mathrm{~K}$. 
It was found that content of proteins in "Candidocyde" VSI corresponds to the norm of $4.0 \pm 0.2 \mathrm{mg} / \mathrm{ml}$; the content of phenol $2.5 \pm 0.2 \mathrm{mg} / \mathrm{ml}$. It was determined that the VSI is transparent and colorless, its $\mathrm{pH}$ value is $7.2 \pm 0.2$. The volume of the container content extracted from "Candidocyde" VSI is not less than the nominal volume specified on the label $-5.0 \mathrm{ml}$. Containers with the VSI are hermetic, the solution does not turn blue. There is no particulate matter in the solution. The studies on sterility have proven that the "Candidocyde" VSI is sterile within the entire storage period.

It should be noted that further studies on developing and improving "Candidocyde" VSI is promising for modern medicine and pharmacy.

\section{References}

[1] Shankargouda P., Barnali M., Sachin C. et al.: Front. Microbiol., 2018, 9, 980. https://doi.org/10.33891/fmicb.2018.00980

[2] Menezes R., Borges A., Araujo L. et al.: Rev. Inst. Med. Trop., 2015, 57, 413. https://doi.org/10.1590/S0036-46652015000500008

[3] Mandelblat M., Frenkel M., Abbey D. et al.: Mycoses, 2017, 60, 534. https://doi.org/10.1101/gr.174623.114

[4] Armstrong-James D., Meintjes G., Brown G.: Trends Microbiol., 2014, 22, 120. https://doi.org/10.1016/j.tim.2014.01.001

[5] Teoh F., Pavelka N.: Pathogens, 2016, 5, 6.

https://doi.org/10.3390/pathogens5010006

[6] Eliakim-Raz N., Babaoff R., Yahav D. et al.: Int. J. Infect. Dis., 2016, 52, 49. https://doi.org/10.1016/j.ijid.2016.09.018

$\lceil 7\rceil$ Denning D., Perlin D., Muldoon E. et al.: Emerg. Infect. Dis., 2017, 23, 177., https://doi.org/10.3201/eid2302.152042

[8] Ronen B.: J. Fungi, 2018, 3, 97.

https://doi.org/10.3390/jof4030097

[9] Bongomin F., Gago S., Oladele R. et al.: J. Fungi, 2017, 3, 57. https://doi.org/10.3390/jof3040057

[10] Reales-Calderon J., Molero G., Gil C. et al.: Future Med.

Chem., 2016, 8, 1503. https://doi.org/10.4155/fmc-2016-0051

[11] Hirakawa M., Martinez D., Sakthikumar S. et al.: Genome Res., 2015, 25, 413. https://doi.org/10.1101/gr.174623.114

「12] Liu J., Shi C., Wang Y. et al.: China. Res. Microbiol., 2015,

166, 153. https://doi.org/0.1016/j.resmic.2015.02.009

[13] Jensen R., Astvad K., Silva L. et al.: J. Antimicrob. Chemother., 2015, 70, 2551. https://doi.org/10.1093/jac/dkv140
[14] Gut-Landman S., Wutrich M., Hohl T.: Curr. Opin. Immunol., 2012, 24, 1. https://doi.org/10.1016/j.coi.2012.04.007

「15] Navalkele B., Revankar S., Chandrasekar P.: Expert Rev. AntiInfe., 2017, 9, 819. https://doi.org/10.1080/14787210.2017.1364992 [16] Gloria H., Jose A., Norman P.: Front. Immunol., 2018, 9, 897. https://doi.org/10.1172/JCI98685

[17] Portuondo D., Ferreira L., Urbaczek A. et al.: Med. Mycol., 2015, 53, 69. https://doi.org/10.1093/mmy/myu045

[18] Medici P., Poeta D.: Mem. Inst. Oswaldo Cruz., 2015, 8, 966. https://doi.org/10.1590/0074-02760150335

[19] Xiao-Juan W., Xue S., Lan Y. et al.: Virulence, 2015, 4, 309. https://doi.org/10.4161/21505594.2014.983015

[20] Rybalkin M., Filimonova N., Diadiun T. et al.: Int. J. Pharm. Sci. Res., 2016, 7, 1035. https://doi.org/10/31040/ IJPSR.09758232.7(3).1035-38

[21] Shevchuk L., Aftanaziv I., Falyk T.: Chem. Chem. Technol., 2017, 11, 475. https://doi.org/10.23939/chcht11.04.475

[22] Yavorskiy V., Suchatskiy Y., Znak Z. et al.: Chem. Chem. Technol., 2016, 10, 507. https://doi.org/10.23939/chcht10.04.507 [23] Derzhavna Farmakopeia Ukrainy. RIREH, Kharkiv 2014, 724.

Received: February 20, 2019 / Revised: May 05, 2019/ Accepted: September 30, 2019

\section{ХІМІЧНИЙ АНАЛІЗ І ДОСЛІДЖЕННЯ ПОКАЗНИКІВ ЯКОСТІ ІМУНОБІОЛОГІЧНИХ ЛІКІВ ДЛЯ ПРОФІЛАКТИКИ І ЛІКУВАННЯ КАНДИДАЛЬНИХ ІНФЕКЦІЙ}

\begin{abstract}
Анотація. Встановлено, що такі показники якості як вміст білка, вміст полісахариду, вміст фенолу та рН розробленого вакцинального розчину для ін'єкцій (BPI) "Кандидоцид" на основі клітин грибів C. albicans та C. tropicalis, відповiдають стандартним вимогам. Визначено, щзо за показником прозорості та ступенем помутніння досліджуваний розчин $\epsilon$ прозорим, за ступенем забарвлення - безбарвний, за показником стерильності - стерильний. Період стерильності, визначений після першого відкриття, становить 8 год. Встановлено, що у розчині відсутні тверді частинки; ємність з розчином герметична; об'єм ємності з розчином не менше 5,0 мл. Досліджуваний розчин є стабільним протягом 2 років зберігання за температури 275-265 K.
\end{abstract}

Ключові слова: вакиина, антиген, хімічний склад, білки, полісахариди. 